\title{
Michael Kaback: people and places
}

\author{
Michael M. Kaback, MD, FACMG ${ }^{1,2}$
}

People and places are the catalysts of most people's careers. They certainly were for mine. From Overbrook High School in Philadelphia in 1955 (yes, Wilt Chamberlain was my classmate and buddy), I entered Haverford College, where each biology major worked closely with a mentor in cutting-edge research. My first publication, coauthored with my mentor, I. Finger, was a study of the genetic and environmental factors involved in the expression of Paramecium aurelia antigens. ${ }^{1}$

In 1959, I entered the University of Pennsylvania School of Medicine and participated in research on chick embryo myogenesis, with $\mathrm{H}$. Holtzer. Clinical rotations in my third year led me to Lew Barness and Bill Mellman, my first exposure to human/medical genetics and “inborn errors." I was smitten! Bill got me into Paul Moorehead's Wistar Institute laboratory, where human karyotyping with phytohemagglutinin-stimulated lymphocytes was first accomplished. With their guidance, I learned to produce quality karyotypes. With Bill away my senior year, I "became" the clinical cytogenetics laboratory for the entire University Hospital - a period when a karyotype was wanted, it seemed, on almost every patient!

Pediatrics was the obvious field for one interested in developmental medicine and inborn errors. In 1963, I became a pediatric intern at the Johns Hopkins Hospital, using every opportunity to seek out and hear Barton Childs, Rod Howell, and Victor McKusick. I also met David Rimoin, Victor's fellow, the beginning of a lifelong friendship. The next year, in lieu of Saigon, I entered the Public Health Service's Research Associate Program at the National Institutes of Health in Bethesda. For 2 years, I studied gene expression during sporulation in Bacillus subtilis in the laboratory of E. Freese, focusing on enzymology, protein purification, and molecular biology. ${ }^{2}$

In 1966, I returned to Hopkins to complete my pediatric residency. Robert Cooke, my chairman, allowed me to split my time so I could also be a fellow in Rod Howell's laboratory, carrying out genetic studies in mammalian tissue. I became proficient in the cultivation of normal human skin fibroblasts and applied these techniques to the diagnosis and detection of heterozygotes in several lysosomal storage disorders. ${ }^{3}$ A closet next to Rod's laboratory became my tissue culture facility for the next 5 years.

In 1968, I joined the faculty at Hopkins and began studies on nucleic acid metabolism in skin fibroblasts cultured from
Down syndrome patients. At that time, a visiting lecturer, Henry Nadler, presented a fascinating seminar on cultured amniotic fluid cells and intrauterine fetal diagnosis, obviously relevant to my Down syndrome work because we had found DNA synthesis rates were delayed in Down syndrome fibroblasts during exponential growth in vitro. ${ }^{4}$ The in vivo correlate, perhaps, was in fetal life, hence my interest in amniotic cell cultivation and prenatal diagnosis. Accordingly, we initiated a laboratory for second-trimester prenatal diagnosis. This possibility of prenatal diagnosis invigorated genetic counseling and greatly changed the outlook for couples at risk for genetic disorders on the basis of family history or other factors, e.g., maternal age.

John O'Brien from the University of California, San Diego, came to Hopkins in 1969 for a mini-sabbatical with Victor McKusick. Rod offered John space in our laboratory, where we worked side-by-side and became lasting friends. He and Shintaro Okada had just discovered the deficiency of hexosaminidase A in Tay-Sachs disease (TSD) and had demonstrated reduced activity of the enzyme in heterozygotes as well. In my clinical role that year, I encountered members of two familiesBayla and Harold Gershowitz, and Karen and Bob Zeigerwhose lives were devastated by the diagnosis of TSD in each family. The enormous love and devotion of each couple for each other and for their affected child had a profound impact on my thinking. Moreover, TSD was remarkable for three reasons: occurrence in a defined population, detectability of healthy heterozygotes, and the possibility of prenatal diagnosis. In short, it was feasible to identify at-risk couples in the defined population through "carrier screening", enabling carrier couples to choose to have unaffected offspring.

Thus, the notion of "prospective prevention" of TSD became paramount. With the tremendous assistance of the Zeiger and Gershowitz families, we planned a pilot program of community-based education, voluntary "carrier" testing, and genetic counseling to "control" TSD in the Jewish communities of Baltimore, MD, and Washington, DC. Funding, personnel, modified laboratory methods and their automation, and educational vehicles had to be developed for such an unprecedented effort. Large-scale community representation was required.

After 1 year of planning, the first community-based testing was held on a rainy Sunday afternoon in May 1971 at a temple in Bethesda, MD. With the help of 40 trained lay volunteers

${ }^{1}$ Department of Pediatrics, University of California, San Diego School of Medicine, San Diego, California, USA; ${ }^{2}$ Department of Reproductive Medicine, University of California, San

Diego School of Medicine, San Diego, California, USA. Correspondence: Michael M. Kaback (mkaback@ucsd.edu) 
and 15 physicians, more than 1,500 people volunteered for testing and were processed through the "system" in about 5 hours. For me, it was like having written a symphony and hearing it for the first time-and it went beautifully, without glitches. ${ }^{5}$ The effort drew much publicity, and programs were soon initiated in Jewish communities throughout North America. Similar programs were started in Israel, South Africa, Australia, Brazil, and Mexico, as well as in Europe. My frequent flyer mileage became enormous.

From the outset, I envisioned the TSD program as a model applicable to other serious autosomal recessive disorders. Sickle cell disease met the first two of the aforementioned three criteria, but the gene for the beta chain of globin supposedly was not "turned on" in early human fetal life. However, with Morley Hollenberg and Haig Kazazian, we soon demonstrated that human beta chain could be detected as early as at 10 weeks of gestation. ${ }^{6}$ The minimal fetal blood requirement needed led to a number of fetoscopic research efforts and placental sampling procedures that made such assessments possible. The model was then used with some modification and great success by Antonio Cao and Renzo Galanello in Sardinia ${ }^{7}$ for the "control" of beta-thalassemia in southern Italy (and subsequently throughout the Mediterranean region).

Early on, these unprecedented efforts in genetic disease "control" and "public health genetics" raised unique and challenging ethical, social, and complex new legal issues. Kurt Hirschhorn in New York asked me to join the Hastings Center Group on Genetic Engineering to elaborate on and publish our considerations about this new area of "public health genet-

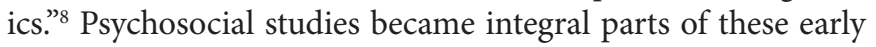
"screening experiments."

In 1972, I joined David Rimoin at the Harbor-UCLA Medical Center in Los Angeles and started the Prenatal Diagnosis and Genetic Counseling Center in the Division of Medical Genetics. Furthermore, I wanted to expand the TSD experience to a statewide program; thus, the California TSD Prevention Program began. As Los Angeles had the second largest Jewish population in the world and California has several other sizable urban areas with Jewish communities, it was enormously helpful to have Mitchell Golbus in San Francisco head up the Northern California effort and Kenneth Lyons Jones be responsible for the San Diego component. With David's guidance, and assistance from Dick Koch of Children's Hospital Los Angeles, Henry Waxman of the California State Assembly, Anthony Bielenson of the California State Senate, and Willie Brown, House Speaker, the California Tay-Sachs Disease and Sickle Cell Anemia Act was enacted.

With so many colleagues throughout the United States and the world buying into this new approach for their communities, I felt a responsibility to help optimize their programs and laboratory methods and to monitor the impact of our aggregate efforts. Thus, an International Quality Control, Reference Standard, and Data Collection Center was established at Harbor-UCLA with the support of the National Tay-Sachs and Allied Diseases Association in New York. This program continues under the direction of M. Blitzer at the University of Maryland. Meanwhile, at Harbor-UCLA, with David, Larry Shapiro, T. Mohandas, and many others, the following years were highly productive. By 1986, our faculty, counselors, staff, and fellows numbered more than 80. From 1972 to 1986, we trained more than 75 fellows in medical genetics, many of whom went on to leadership positions in medical genetics around the world.

In 1986, I moved to San Diego as Chairman of Pediatrics and head of the Division of Medical Genetics in Pediatrics at University of California, San Diego, and Pediatrician-inChief at San Diego Children's Hospital. The California TSD Prevention Program moved as well. In 2006, I retired from University of California, San Diego, and the California TSD Prevention Program officially ended because testing had been taken over predominantly by private laboratories, with most of them using DNA mutation analysis rather than enzymology for carrier detection.

By 2006, worldwide, more than 1.5 million adults had been tested voluntarily, more than 2,000 at-risk couples had been identified, in excess of 3,200 at-risk pregnancies had been monitored, and more than 625 fetuses had been identified with TSD. Most importantly, more than 2,550 healthy unaffected infants were born to these at-risk families, many of whom might never have been conceived otherwise. In 1970, there were approximately 85 newly diagnosed cases of TSD each year in the United States and Canada. By the year 2000, there was a 95\% decrease in the number of cases in the Jewish populations of North America. ${ }^{10}$ In recent decades, advanced molecular methodologies and greatly expanded multiplex mutation detection techniques have dramatically changed the approach for carrier testing. On the other hand, the complexities of pretest education and posttest counseling have not yet been completely resolved.

The 1980s and 1990s brought other measures of success, including election to multiple boards and officer positions in both the pediatric community and the human/medical genetics communities. As president-elect of the American Society of Human Genetics (ASHG) in 1990 and president in 1991, I had the pleasure of working closely with Jessica Davis and David Rimoin in their committees on the "creation" of the American College of Medical Genetics and Genomics (ACMG) and then serving on its founding board. Although I feel especially honored by my election in 1994 to the Institute of Medicine of the National Academy of Sciences and to a fellowship in the American Association for the Advancement of Science, in addition to receiving the Allen Award (ASHG 1993) and the Colonel Sanders Award (ACMG 2000), these are also testaments to the contributions of many other persons, only some of whom have been noted above.

Clearly, the people and places of my life were the most critical elements in shaping my career, and I am deeply indebted to each of them. Of course, my family had a great deal to do with it, too: I thank them for their love, support, and patience. Thus, to those choosing to pursue a career in genetics, whether clinically or scientifically focused-seek out the "best people" in the 
"best places," and immerse yourself. It can be a wonderful life. It sure has been for me!

\section{DISCLOSURE}

The author declares no conflict of interest.

\section{REFERENCES}

1. Finger I, Kaback M, Kittner P and Heller C. Immunological studies of isolated particulates of Paramecium aurelia. J Biophys Biochem Cytol 1960;8:591-602.

2. Berberich $R$, Kaback M, Freese E. D-amino acids as inducers of L-alanine dehydrogenase in Bacillus subtilis. J Biol Chem 1968;243:1006-1011.

3. Kaback M and Howell R. Infantile metachromatic leukodystrophy: heterozygote detection in skin fibroblasts and possible applications to intrauterine diagnosis. New Eng J Med 1970;282:1336-1340.

4. Kaback $M$ and Bernstein L. Biologic studies of trisomic cells growing in vitro. Annals N.Y. Acad Sci 1970;171:526-537.
5. Kaback M and Zeiger R. Heterozygote Detection in Tay-Sachs Disease: A Prototype Community Screening Program for the Prevention of Recessive Genetic Disorders, Advances in Experimental Medicine and Biology. Plenum Press: New York, 1972;28:862-867.

6. Hollenberg $\mathrm{M}$, Kaback $\mathrm{M}$ and Kazazian $\mathrm{H}$. Synthesis of adult hemoglobin by reticulocytes from the human fetus at midtrimester: possible applications to the prenatal detection of sickle cell anemia and other hemoglobinopathies. Science 1971;171:698-703.

7. Cao A, Rosatelli C, Galanello R, et al. The prevention of thalassemia in Sardinia. Clin Genet 1989;36:277-285.

8. Hastings Center-Committee on Genetic Engineering. Ethical and social issues in screening for genetic disease. New Eng J Med 1972;286:1129-1133.

9. Childs B, Gordis L, Kaback M and Kazazian H. Tay-Sachs screening: social and psychological impact. Amer J Hum Gen 1976;28:550-556.

10. McGinniss $M$ and Kaback $M$. Heterozygote testing and carrier screening In: Rimoin D, Connor M, Pyeritz R, Korf B (eds) Emery and Rimoin's Principles and Practice of Medical Genetics, 5th edn. Churchhill Livingstone, Philadelphia, PA, 2007;1:627-636. 